\title{
Resources
}

Virtually There: Open Access and the Online Growth of Pacific Dissertations and Theses

STUART DAWRS

The Contemporary Pacific, Volume 24, Number 2, 347-357

(C) 2012 by University of Hawai'i Press 


\section{Virtually There: Open Access and the \\ Online Growth of Pacific Dissertations \\ and Theses}

Stuart Dawrs

It has now been more than a decade since the Open Society Institute-the private grant-making foundation begun by George Soros-sponsored a multinational, multidisciplinary gathering in Hungary to, as the institute notes on its website, "accelerate progress in the international effort to make research articles in all academic fields freely available on the internet." Though this event was hardly the first attempt at fostering free online access to scholarly information, the two-day gathering resulted in a position statement called the Budapest Open Access Initiative (BOAI), which came to be seen as a foundational document for the open-access movement as we know it today. To somewhat oversimplify, the movement is a worldwide endeavor rooted in the idea that scholarly writing, produced by authors who have no expectation of payment for their work, should not become a commodity.

The BOAI was not merely an academic exercise, so to speak. Since the mid-I980s, institutional subscription rates for academic journals have risen at an annual rate that has far outpaced inflation. Between 1986 and 200I, when the Budapest meeting was convened, the annual median expenditure for serial publications by libraries in the Association of Research Libraries (ARL) rose from $\$ \mathrm{I}, 496,775$ to $\$ 4,660,349$. In 2009 , that number stood at $\$ 7,193,29 \mathrm{I}$ - a 38I percent increase since I986 or, on average, 7.4 percent per year (Kyrillidou and Morris 20II, IO). Just to be clear, this median cost figure is based on what each individual ARL member library—of which there are 126 in North America and Hawai'ipays each year. As one example, in 2010 the University of Hawai'i paid $\$ 6,5$ I 2,647 for current serials, or roughly 37 percent of all library expenditures (Kyrillidou, Morris, and Roebuck 20I I, 36). ${ }^{2}$

The Contemporary Pacific, Volume 24, Number 2, 348-357

(C) 2012 by University of Hawai' $i$ Press 
While these costs represent all serial expenditures in a given library (academic journals, newspapers, magazines, etc), the cost increases are largely driven by commercially published academic journals. In the world of academic libraries, this situation is often referred to as the "serials crisis" and is perhaps best summarized in a 2005 report by Judith M Panitch and Sarah Michalak, two librarians at the University of North CarolinaChapel Hill:

While the publication of research results was once the purview of scholarly societies, the increased pace of research and concurrent proliferation of specializations that characterized the last thirty years invited the participation of commercial publishers in the review and dissemination of scholarly output. Yet the workings of the system have remained essentially the same: Faculty, supported by the University, produce research results which they then sign over freely to publishers in order to advance knowledge in their field and because most career paths require a distinguished publication record. Faculty members additionally volunteer their time to serve as editors and editorial board members. Commercial publishers find themselves in the enviable position of selling research which they neither produced nor paid for to a high-demand market.... It is hard to imagine an academic context in which research could advance or career decisions could be made without scholarly journals; they have acquired the status of a public good, a common currency of the university.

This then is the context out of which arose the BOAI, with the underlying goal being that, in the name of communication and continued innovation, scholarly work should be made universally available to those who seek it, with no (or as few as possible) barriers to access. "The only constraint on reproduction and distribution," according to the BOAI, "and the only role for copyright in this domain, should be to give authors control over the integrity of their work and the right to be properly acknowledged and cited" (Chan and others 2002). Further, the BOAI called for scholars to begin "self-archiving" their material online in open electronic archives and to found their own freely available electronic journals.

In the ensuing years, several other statements and declarations built on and refined the BOAI; ${ }^{3}$ these clarify, for instance, that open access does not require repealing (or violating) copyright law, but rather asking copyright owners to grant free access to their work, along with the permissions necessary to duplicate or otherwise redistribute that work. Perhaps most importantly (to a librarian, at least), these later refinements also recognized the need to point self-archiving in a direction that would more uniformly, stably, and "permanently" archive items that are created and 
stored digitally. ${ }^{4}$ This concern over uniform digital storage has in recent years given rise to numerous "digital institutional repositories," which in essence serve as virtual additions built onto traditional brick-and-mortar libraries and archives. Most major institutions that support Pacific research now have their own digital repositories, including the University of Auckland, the University of Canterbury, the Australian National University, the University of the South Pacific, and the University of Hawai'i, among many others. ${ }^{5}$ The primary purpose of these repositories is to house the scholarly output of the institutions they are attached to, though some broaden the scope to include digital material from other sources. ${ }^{6}$ True to the вОAI, though the sites are constructed, arranged, and maintained by librarians or other "information professionals," many allow at least some level of self-archiving. At the University of Hawai'i (UH), for instance, the institutional repository known as ScholarSpace is maintained by $\mathrm{UH}$ Mānoa's Hamilton Library. Various academic units throughout the university can request their own "communities" within the repository, after which they can establish their own content and access guidelines. A good case in point is UH Mānoa's Center for Pacific Islands Studies, which has maintained and been steadily populating its own ScholarSpace community since $20 \mathrm{IO}$.

In the academic arena, the open-access movement has from its early days taken as a major concern peer-reviewed writing destined for publication in scholarly journals. In this realm, one doesn't need to look far to see how the movement has benefitted Pacific scholarship. In May 20I0, The Contemporary Pacific (TCP) adopted a model whereby all but the most recent two issues of the journal would be made freely available via UH Mānoa's ScholarSpace. (Current issues, along with back issues through the year 2000, are available on the subscription-only database Project MUSE.) Since the journal was added to ScholarSpace, more than 2I,000 visitors have downloaded more than 40,000 TCP files. Similarly, most of the back-file of more than a hundred years of the Journal of the Polynesian Society is now freely available on a site hosted by the University of Auckland Library (current issues being available through the subscription database Informit). A wide range of electronic journals have also been founded in recent years, among them the University of Auckland's Graduate Journal of Asia Pacific Studies, the University of Guam's Pacific Asia Inquiry, and Te Kaharoa: The e-Journal on Indigenous Pacific Issues. Other journals, formerly published in print, have migrated to online-only formats-one recent example being Language and Linguistics in Mela- 
nesia, which released its first electronic issue in December 20II, after a fourteen-year publishing hiatus.

Beyond the open-access emphasis on scholarly journals, a secondary benefit is now emerging in the form of increased access to master's theses and doctoral dissertations. In the past, Pacific scholars had a fairly limited set of options when it came to accessing these essential building blocks of new research: Those affiliated with well-funded institutions may have been able to use ProQuest, the by-subscription, online database that includes many (but not always all) digital versions of theses and dissertations produced at several major Pacific-related institutions. For those without access to ProQuest, or for those seeking work from institutions that do not participate in ProQuest, the options were progressively unfeasible. One could (a) contact the author directly to request a copy; (b) request that his or her home library acquire a copy from the author's submitting institution (which may or may not be possible, depending on policies at both institutions); (c) contact the holding library or archive directly to request a personal copy (again, subject to institutional policies); or (d) visit the library or archive directly to view the original.

These days, more and more theses and dissertations are finding their way into digital repositories, with many available in full text. For instance, at the time of this writing in December 20II, the University of Auckland had placed 2,657 dissertations and 616 theses in ResearchSpace, its online repository. Of these, I,62 I dissertations and 63 theses are listed as open access-available for download by anyone, anywhere. The Australian National University (ANU) currently shows a total of 445 open-access doctoral or master's submissions in its ANU Research repository. The University of Hawai'i has 3,292 master's theses and doctoral dissertations in ScholarSpace. Obviously, not all of these documents deal with Pacific subjects, but a great many do-UH Mānoa's Center for Pacific Islands Studies, for instance, recently completed a project to scan Plan A theses and Plan в projects submitted to its Master of Arts program; I34 of these documents are now available in full text on ScholarSpace. Also at the time of this writing, the University of California at San Diego's Melanesian Archive was preparing to upload 52 dissertations concerning anthropology of the Papua New Guinea Highlands to its Digital Library Collections repository.

Theses and dissertations are clearly of a different class of writing than material produced expressly for publication. Because of this distinction, institutions are taking varied approaches when it comes to releas- 
ing them into the wild, as it were. For instance, according to information posted on the University of Auckland's digital repository pages, all dissertations submitted by $\mathrm{PhD}$ candidates enrolling as of 2007 must include a digital version, which is by default added to the institutional repository in open-access mode, though authors are given the option to place greater restrictions on access. Master's candidates, meanwhile, have been required to submit digital versions of their theses since January 20II, with the default setting of "Campus Access" (ie, available only to the University of Auckland community), though authors canwith departmental permission—request that their work be made either open access or further restricted. At the Australian National University, depositing graduate-level work in the ANU Research repository is voluntary. At the University of Hawai'i at Mānoa, which is currently assessing a transition to digital submission of dissertations and theses, the default for those that are already posted online is open access, though individual authors can choose to further restrict their works. (The majority of the 3,000-plus UH dissertations and theses that are currently available through ScholarSpace are not new digital submissions but rather part of a grant-funded digitization project targeting several decades worth of hard-copy submissions that were not previously available via ProQuest or other online databases.)

As campuses worldwide continue to adopt their own open-access policies for theses and dissertations, the online numbers can only continue to grow. Thankfully, the tools for discovering them are becoming more robust, with several free, online search engines now offering simultaneous searches across numerous institutional repositories. At the same time, these new engines allow for a much more refined search than is often possible via everyone's favorite default, Google Scholar. ${ }^{7}$ Four such tools of particular note are Trove; the Kiwi Research Information Service (KRIS); OAIster; and the Networked Digital Library of Theses and Dissertations (NDLTD). Trove, which is hosted by the National Library of Australia, searches a broad array of content produced throughout Australia, from early newspapers to photographs to scholarly content. It's a massive archive of material, but one can use the "advanced search" function to easily limit results specifically to online theses. KRIS, produced by the National Library of New Zealand, is a bit more focused than Trove, limiting its searches from the outset to open-access research documents produced at a dozen New Zealand institutions, among them Lincoln University, Massey University, 
the University of Auckland, the University of Canterbury, the University of Otago, the University of Waikato, and Victoria University of Wellington. OAIster, which is maintained by the nonprofit international library cooperative known as OCLC (Online Computer Library Center), broadens the Trove search model to a global scale-or, as is noted on the OAIster website, to "More than 23 million records representing digital resources from more than I, IOO contributors." Finally, as its name implies, the NDLTD searches for dissertations and theses from a worldwide collective of member institutions and consortia. Some, like the University of Hawai'i or Massey University, are well known to Pacific scholars; others might typically be less visible: Basic test searches of the NDLTD using broad terms such as "Melanesia" retrieve writing from Sweden's Gotland University and Brazil's Universidade de São Paulo, among others.

It should be noted here that the ability to search across the digital holdings of institutions worldwide, while a boon to researchers, does have its shortcomings. Standards for digital repositories vary from institution to institution, both in terms of what meta-data is applied to individual records (which, in turn, determines how search engines discover each work) and in terms of what material is loaded into the repositories in the first place. For instance, searches in the NDLTD will not automatically distinguish between an undergraduate honors thesis and a master's thesisa situation that can occasionally turn up academically suspect material. Ultimately, it is up to the individual repositories to decide what gets posted and how it is described, so this is the occasional dark side of self-archiving: Any given online record is only as good as the meta-data applied by its creator. It is also not uncommon when using the larger global search engines to see a variety of inconsistencies, such as multiple copies of the same record appearing in search results.

Finally, it should go without saying that anyone who thinks everything in the world is now online is wildly delusional. One of the dangers in singing the praises of online access to some material is that it makes other lesser-known print collections all the more invisible. This is particularly true of primary source, manuscript research collections that are only held in one place worldwide, and may or may not ever enter the digital realmin other words, a great deal of Pacific-related material. Still, with these caveats in mind, institutional repositories and search engines like Trove, the NDLTD, and so on can only help broaden the foundation on which new Pacific research is built. 


\section{Notes}

I The web addresses (URLS) for the BOAI site and other websites mentioned in this essay are listed in Appendix I.

2 For ARL reporting purposes, this budget statistic includes the University of Hawai'i at Mānoa Library-the university's main library, which is housed in two buildings, Hamilton and Sinclair-as well as the UH Richardson School of Law Library and the Health Sciences Library of the John A Burns School of Medicine.

3 Among these statements and declarations are the Association of College and Research Libraries (ACRL) Principles and Strategies for the Reform of Scholarly Communication (2003); the Bethesda Statement on Open Access Publishing (2003); the Berlin Declaration on Open Access to Knowledge in the Sciences and Humanities (2003); the UN World Summit on the Information Society Declaration of Principles and Plan of Action (2003); the Organisation for Economic Co-operation and Development (OECD) Declaration on Access to Research Data From Public Funding (2004); the International Federation of Library Associations and Institutions (IFLA) Statement on Open Access to Scholarly Literature and Research Documentation (2004); the Adelphi Charter on Creativity, Innovation and Intellectual Property (2005); and the Rio Declaration on Open Access (2006).

4 Digital permanence is a topic of debate among librarians-I am skirting the issue here by speaking solely of the benefits of heightened digital access and not of the numerous questions surrounding how or whether a "born digital" item can achieve the kind of longevity displayed by, for instance, the numerous eighteenthcentury Pacific voyaging accounts housed in libraries worldwide.

5 At the time of this writing, the University of the South Pacific digital theses repository was off-line for maintenance.

6 Many universities now maintain multiple digital repositories. Policies vary from institution to institution, but typically one repository is designated for work produced by researchers affiliated with the institution (usually faculty or graduate students), while others house digital material that derives from other sources. As one example, the University of Hawai'i's Hamilton Library currently maintains two repositories-ScholarSpace and eVols, with the former being the institutional repository and the latter holding material that the library or university has digitized from other sources.

7 Google Scholar, the subset of Google that ostensibly allows one to limit searches to scholarly content, can at times be a useful tool for global literature searches, but for the more narrow purpose of searching dissertations and theses, it is very messy. Google Scholar searches do crawl institutional repositories, but they cannot be limited solely to dissertations and theses, and search results can only be sorted in the most rudimentary ways. 


\section{References}

Chan, Leslie, Darius Cuplinskas, Michael Eisen, and others

2002 Budapest Open Access Initiative. Budapest, Hungary, I4 February.

Online at http://www.soros.org/openaccess/read [accessed 5 December 2OII]

Kyrillidou, Martha, and Shaneka Morris, compilers and editors

20I I ARL Statistics, 2008-2009. Washington, DC: Association of Research Libraries.

Kyrillidou, Martha, Shaneka Morris, and Gary Roebuck, compilers and editors 2OI I ARL Statistics, 2009-20IO. Washington, DC: Association of Research Libraries.

Panitch, Judith M, and Sarah Michalak

2005 The Serials Crisis: A White Paper for the UNC-Chapel Hill Scholarly Communications Convocation. January. Chapel Hill, NC: Panitch \& Michalak. Online at http://www.unc.edu/scholcomdig/whitepapers/ panitch-michalak.html\#_ftnI [accessed 5 December 20II]

Appendix. Open-access and Research Websites

\begin{tabular}{|c|c|c|}
\hline Website Name & Host & URL \\
\hline $\begin{array}{l}\text { ANU Research } \\
\text { repository }\end{array}$ & $\begin{array}{l}\text { The Australian } \\
\text { National University }\end{array}$ & $\begin{array}{l}\text { https://digitalcollections.anu.edu.au/ } \\
\text { handle/1885/3 }\end{array}$ \\
\hline $\begin{array}{l}\text { Budapest Open } \\
\text { Access Initiative }\end{array}$ & $\begin{array}{l}\text { Open Society } \\
\text { Institute }\end{array}$ & http://www.soros.org/openaccess \\
\hline $\begin{array}{l}\text { Digital Library } \\
\text { Collections }\end{array}$ & $\begin{array}{l}\text { University of } \\
\text { California-San Diego }\end{array}$ & $\begin{array}{l}\text { https://libraries.ucsd.edu/digital/ } \\
\text { \#home }\end{array}$ \\
\hline eVols & $\begin{array}{l}\text { UH Mānoa Hamilton } \\
\text { Library }\end{array}$ & http://evols.library.manoa.hawaii.edu/ \\
\hline Google Scholar & Google & http://scholar.google.com \\
\hline $\begin{array}{l}\text { Graduate } \\
\text { Journal of Asia } \\
\text { Pacific Studies }\end{array}$ & $\begin{array}{l}\text { University of } \\
\text { Auckland School } \\
\text { of Asian Studies }\end{array}$ & $\begin{array}{l}\text { http://www.arts.auckland.ac.nz/uoa/ } \\
\text { home/about/departments-and-schools/ } \\
\text { school-of-asian-studies/graduate } \\
\text {-journal-of-asia-pacific-studies }\end{array}$ \\
\hline
\end{tabular}

(continued on next page) 
Appendix. Open-access and Research Websites (continued)

\begin{tabular}{|c|c|c|}
\hline Website Name & Host & URL \\
\hline Informit & RMIT Publishing & http://www.informit.com.au/ \\
\hline $\begin{array}{l}\text { Journal of the } \\
\text { Polynesian } \\
\text { Society }\end{array}$ & $\begin{array}{l}\text { University of } \\
\text { Auckland Library }\end{array}$ & $\begin{array}{l}\text { http://www.jps.auckland.ac.nz/ } \\
\text { index.php }\end{array}$ \\
\hline $\begin{array}{l}\text { Kiwi Research } \\
\text { Information } \\
\text { Service (KRIS) }\end{array}$ & $\begin{array}{l}\text { National Library } \\
\text { of New Zealand }\end{array}$ & http://nzresearch.org.nz/ \\
\hline $\begin{array}{l}\text { Language and } \\
\text { Linguistics in } \\
\text { Melanesia }\end{array}$ & $\begin{array}{l}\text { University of Papua } \\
\text { New Guinea }\end{array}$ & http://www.langlxmelanesia.com/ \\
\hline $\begin{array}{l}\text { Networked } \\
\text { Digital Library } \\
\text { of Theses and } \\
\text { Dissertations } \\
\text { (NDLTD) }\end{array}$ & NDLTD & http://www.ndltd.org/find \\
\hline OAIster & $\begin{array}{l}\text { Online Computer } \\
\text { Library Center } \\
\text { (oCLC) }\end{array}$ & $\begin{array}{l}\text { Website: http://www.oclc.org/oaister } \\
\text { Search engine: } \\
\text { http://oaister.worldcat.org/ }\end{array}$ \\
\hline $\begin{array}{l}\text { Pacific Asia } \\
\text { Inquiry }\end{array}$ & University of Guam & $\begin{array}{l}\text { http://www.uog.edu/dynamicdata/ } \\
\text { CLASSPacificAsiaInquiry.aspx }\end{array}$ \\
\hline Project MUSE & $\begin{array}{l}\text { Johns Hopkins } \\
\text { University Press }\end{array}$ & http://muse.jhu.edu/ \\
\hline ProQuest & $\begin{array}{l}\text { Cambridge } \\
\text { Information Group }\end{array}$ & http://www.proquest.com/ \\
\hline ResearchSpace & $\begin{array}{l}\text { University of } \\
\text { Auckland }\end{array}$ & https://researchspace.auckland.ac.nz/ \\
\hline ScholarSpace & $\begin{array}{l}\text { UH Mānoa Hamilton } \\
\text { Library }\end{array}$ & http://scholarspace.manoa.hawaii.edu/ \\
\hline $\begin{array}{l}\text { Te Kaharoa: } \\
\text { The e-Journal } \\
\text { on Indigenous } \\
\text { Pacific Issues }\end{array}$ & $\begin{array}{l}\text { Auckland University } \\
\text { of Technology }\end{array}$ & http://www.tekaharoa.com \\
\hline
\end{tabular}

(continued on next page) 
Appendix. Open-access and Research Websites (continued)

\begin{tabular}{lll}
\hline Website Name & Host & URL \\
\hline Trove & $\begin{array}{l}\text { National Library } \\
\text { of Australia }\end{array}$ & http://trove.nla.gov.au/ \\
Digital Library & University of & https://libraries.ucsd.edu/ \\
Collections & California-San Diego & digital/\#home \\
Usp Digital & University of the & http://uspdl.library.usp.ac.fj/thesis \\
$\begin{array}{l}\text { Theses } \\
\text { Repository }\end{array}$ & South Pacific & \\
\hline
\end{tabular}

